\title{
A lélek halhatatlanságának problematikája a Phaidónban és egy XVIII. századi Platón-interpretációban
}

\section{A lélek halhatatlansága a görög hagyományban}

A lélek halhatatlansága az orphikus tanokban bukkant fel elôször az emberi lét alapkérdéseként a görög kultúrában ${ }^{1}$, s a püthagoreus filozófián keresztül került be a filozófiai hagyományba. Platón kérdésfelvetése, a hasonlóságok ellenére is, jelentôsen különbözik a püthagóraszi hagyományoktól. A lélek halál utáni élete nála nem kapcsolódik össze a jutalom és büntetés orphikus gondolatával ${ }^{2}$. A problémát sokkal inkább a filozófikus élet és az erkölcsi jó vonatkozásában értelmezi, mintsem az istenek világának olyan terrénumaként, amelybe lehetséges volna valamiféle közösségi kultuszon keresztül történő beavatás. ${ }^{3} \mathrm{~A}$ platóni dialógusok felfogását vizsgálva tehát tisztázni kell $\mathrm{Pla}$ tónnak a szicíliai püthagoreusokkal való kapcsolatát, de figyelemmel kell lenni azokra a lehetséges forrásokra is, ahonnét a lélek halhatatlanságának gondolata az elooző iskola interpretációinak módosított változataként beszüremkedve segíthette Platónt saját, minden korábbinál átfogóbb gondolatrendszerbe illesztett halhatatlanságképének megalapozásában.

$\mathrm{Az}$ alapkérdés végül is az, hogy hogyan hozható összefüggésbe a lélek halhatatlanságának gondolata a platóni filozófia más problémáival, illetve az, hogy ṁenynyiben tekinthető olyan problémának, amely a platóni filozófia lényege felól közelítve igazolná Platón és a preszókratikus hagyományok közötti folytonosságot. Azokban a filozófiatörténeti korszakokban, amikor a platóni életmű a filozófiai értelmezések középpontjába került - leginkább Plotinosz és a többi újplatonikus, a firenzei neoplatonizmus és a felvilágosodás esetében ${ }^{4}$ - a lélek halhatatlanságának kérdése kiemelt szerepet kapott. Ezeknek a múveknek és interpretációknak - jelen esetben Mendelssohn Phaidón-fordításának - a vizsgálata, a filozófiatrörténeti érdekességén túl, talán abból a szempontból is hasznos lehet, hogy egy hermeneutikai szempontú megközelítés elősegítheti az eredeti probléma értelmezését.

\section{A lélek preegzisztenciája kérdésének püthagoreus háttere}

Platón és a püthagoreusok kapcsolatát a legtöbb történeti feldolgozás tényként fogadja el, és kezdetét a szicíliai út időszakára datálja. Valószínünek tartják azt is, hogy az Arkhütasz által vezetett közösség megismerése szerepet játszott az Akadémiának mint szellemi közösségnek a kialakításában. ${ }^{5} \mathrm{Az}$ Akadémia jelmondata álítólag ez volt: „Ne lépjen be ide az, aki nem ismeri a geometriát”. ${ }^{6}$ A püthagoreus közösségek mintáján és a geometria fontosságának kiemelésén túl a lélekvándorlás gondolatát is hasonló átvételnek tartja a szakirodalom. A lélek halhatatlanságának gondolata azonban Platónt megelózően jó néhány közismert auktornál is elöfordul. Plutarkhosz az egyiptomi gyökerekre utal vissza Izisz és Oszirisz címú múvében?. Arisztophanész $A$ Béke címü komédiájában szereplő rabszolga érdeklödik Trygaiostól a holtak lelkeinek 
sorsáról ${ }^{8}$. Mindezek alapján Burkert arra a következtetésre jut, hogy tévedés lenne Platón esetében a fenti problematikát kizárólag és közvetlenül a püthagoreusokra visszavezetni. ${ }^{9}$

A püthagoreus hagyomány a geometrián keresztül először a Menónban kap kulcsszerepet, de az anamnézis kapcsán megtalálható itt a lélek halhatatlansága is. A Gorgiaszban és a Menónban felbukkanó eszkatalogikus mítosz, a mûvek keletkezési idejét tekintve is, az első szicíliai úttal hozható összefüggésbe. A Phaidónban az ismeretelméleti vonatkozásokkal szemben az etikai dimenzió még inkább elótérbe kerül. ${ }^{10} \mathrm{~A}$ Szókratész perével és halálával kapcsolatos múvekben különösen aktuális és történetileg is hiteles a filozofálás és a halálra való felkészülés mozzanatának összekapcsolása, s etikai problémaként való felmutatása, olyannyira, hogy Taylor feltételezése szerint Szókratésznak a Phaidónban kifejtett gondolatai nincsenek is közvetlen megfelelésben Platón álláspontjával, s a szókratészi elgondolásnak is csak részleges, szituációfüggő megnyilatkozásai." ${ }^{11}$ Szókratész példájának konkrét megjelenítése kapcsán azonban még akkor is illeszkedniük kell ezeknek a dialógusoknak a platóni életmû́ egészébe, ha azokat egyfajta ,jegyzókönyvként” fognánk fel, hiszen részei azon - az Államig vagy akár a Törvényekig terjedő - müvek sorának, amelyek a Platón által mintául szánt filozófusi magatartást reprezentálják.

$\mathrm{Az}$ a gondolat, hogy a halál nem valami rossz, amitól félni kellene, először az Apológiában bukkan fel: „Én azt hiszem, hogy az, ami most velem történt, valami jó volt, és hogy helytelenül fogjuk fel a dolgot mi emberek, ha azt hisszük, hogy a halál rossz" (40 c). Mivel ezt a következtetést abból vonja le, hogy ha a halál rossz lenne, daimónja figyelmeztette volna ót erre, s a daimónnak Hérakleitosztól kezdődően van személyes, etikai mozzanata ${ }^{12}$, az Apológia kérdésfelvetése már elólegezi a
Phaidónnak azt a sajátosságát, amit Taylor így fogalmazott meg: „A beszélgetés közvetlen és fő céljaként a „lélek gondozásának" szentelt élet igazolását jelölhetnénk meg ... (...) A lélek haláltól való mentessége csupán következménye - bár semmiképpen nem elhanyagolható következménye - a lélek elidegeníthetetlen isteni természetének." ${ }^{13}$

A fentiekból adódik a Phaidón gondolatmenetének az a - Szókratész által is hangsúlyozott - sajátossága, hogy a lélek halhatatlanságára nem ad teljes bizonyítást, annak ellenére, hogy az érvelés során három eltérő szempont is fölvetődik:

1. a visszaemlékezés tanára vonatkozó bizonyítékok

2. a lélek egyszerúségéból és elpusztíthatatlanságából levezetett bizonyítás

3. a lélek a vele ellentétes fogalmat, a halált, nem foglalhatja magában.

Az, hogy a lélek halhatatlansága nem nyer teljeskörü bizonyítást, a dialógus püthagoreus vonatkozásaiból is adódik. Mivel a feltételezések szerint a Szókratész utolsó óráiról szóló beszámoló egy püthagoreus közösség előtt hangzik el, és a dialógus ellenérveket hozó szereplői, Szimmiasz és Kebész bizonyítottan ebból az iskolából valók ${ }^{14}$, a szókratészi módszer (Phaidón, 95e - 102a) értelmében történő kifejtés alapvető posztulátuma ebben a szellemi közegben nem képezheti vita tárgyát. Szimmiasz ellenérvének megcáfolása például éppen azon alapul, hogy Szókratész vitapartnere is valósnak fogadja el a lélek preegzisztenciáját (77 a). Hasonló egybehangzás figyelhető meg a formák utánzásának szókratészi kifejtésében is, hiszen Szókratész csak a harmadik érvben veti fel a püthagoreus felfogáson túlmutató részesedéselméletet.

A lélek halhatatlanságának platóni érvredszerét a Phaidrosznak a lélek önmozgására irányuló gondolatai elólegezik, részletesebb kifejtését viszont csak a Törvények tizedik könyvében nyeri el. ${ }^{15} \mathrm{~A}$ lélek mozgására irányuló érvek e könyvek- 
ben kifejtett hátterét a kozmológia szolgáltatja. A Phaidónban ez az érvrendszer és analógia nem jelenik meg közvetlenül. A Kebész-féle harmóniafelfogás talán csak az egyetlen, ami mögött ez a kozmológiai analógia feltételezhetô. Taylor ezt az ellenérvet a szicíliai orvosiskolának az egészséget mint harmóniaként értelmező tanaiból eredezteti ugyan ${ }^{16}$, de egy Philolaosz tanítvány esetében legalább ilyen evidens harmóniaminta lehetett mesterének a bolygók egyensúlyára vonatkozó tanítása. ${ }^{17}$ Növeli ennek az értelmezési háttérnek a fontosságát az is, hogy a Timaioszban az isteni jóindulat nemcsak a lélek, hanem a teremtett istenek, az állócsillagok halhatatlanságának záloga is ${ }^{18}$, $\mathrm{s}$ a gondolatmenetben szerepet kap a mozgás harmóniája is (Timaiosz, 41 a-b). Burkert szerint az újra és újra felbukkanó püthagoreus elemek hatásának egyfajta belső logikáját voltaképp az adja meg a platóni életmúben, hogy idóben elörehaladva belólük éppen az asztrológiai vonat- kozások meghatározó szerepe válik egyre nyomatékosabbá. ${ }^{19}$

\section{A halállal való foglalkozás mint a lé- lek gondozásának mozzanata}

A Phaidónban a halhatatlanság mellett felhozott első érvben (70c-77d) mutatkoznak meg legpregnánsabban a püthagoreus elemek. Az élet és a halál egymásból keletkezésének gondolata a lélekvándorlás, az anamnésziszé pedig a lélek preegzisztenciájának tanára utal vissza, az öngyilkosság tilalma kapcsán pedig Philoláosz neve is elókerül (61e). A halálra ítélt Szókratész magatartásmintáján keresztül a filozófus halállal való foglalkozása egyidejúleg kap etikai és ismeretelméleti értelmezést.

Szókratésznak ,az olykor jobb meghalni, mint élni" gondolatára Kritón egy alkalommal a „kedv” szót használva utal viszsza, azt az általános felfogást követve, amely a halált - Szókratész gondolkodás-

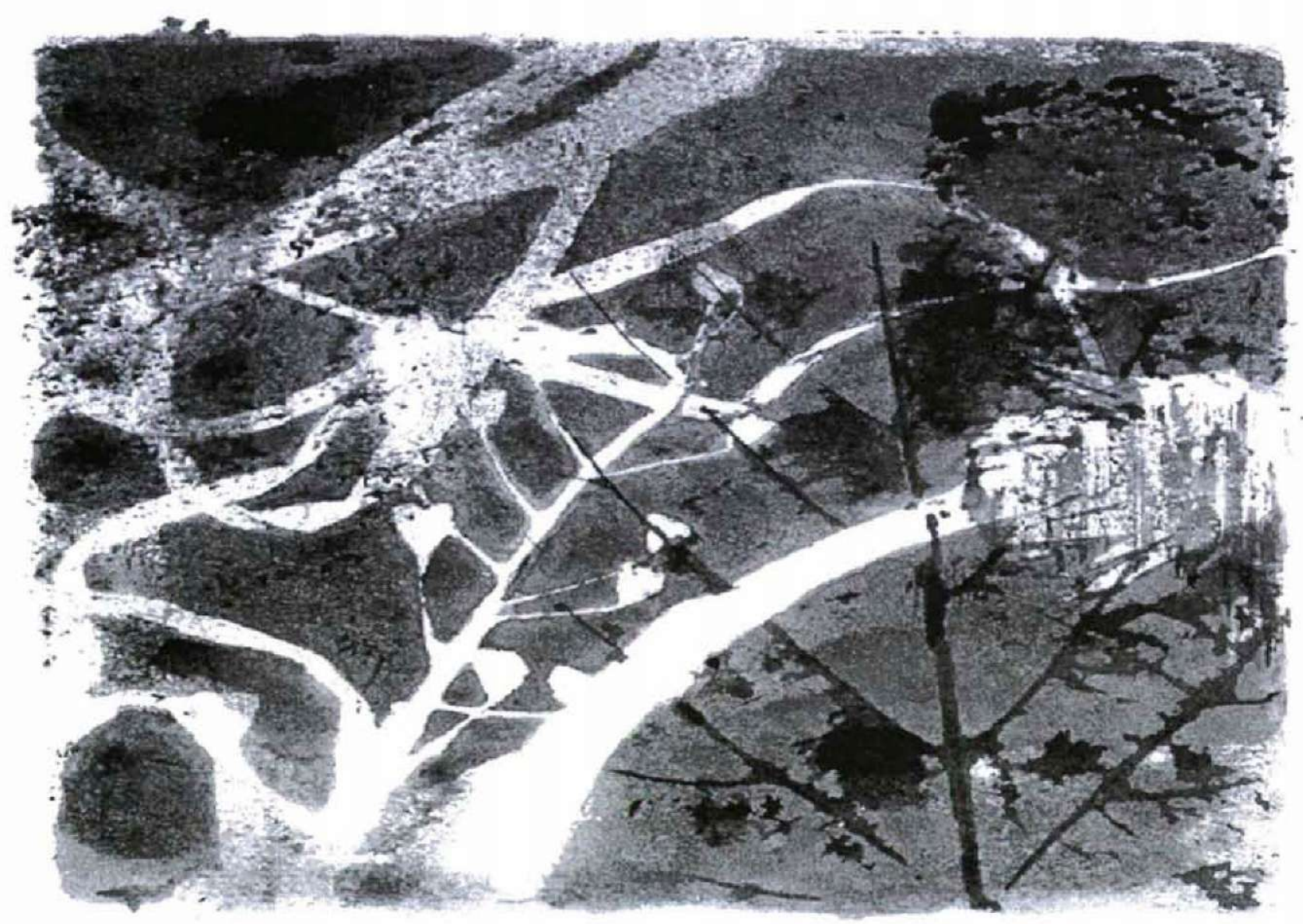


módjától eltérően - csupán a földi élet felól értelmezi. Szókratész a jó kategóriájának rendei alá az életet, amelyben nem a halál, hanem a test és a lélek szembeállítása jelenti a cezúrát. Szókratész fenti gondolata akkor értelmezhetô valódi jelentésében, ha a jó fogalmát a lélek prioritását szem elött tartva értelmezzük. A léleknek a testi kötöttségektól való megtisztulása ${ }^{20}$ teljes egészben csak a halállal történik meg, de maga a megtisztulás követendő és követhető jó a földi élet számára. A Phaidónban a léleknek a testiség rácsai mögül való részleges kiszabadítását, megtisztulását célozza minden, a gondolkodással összefüggő tevékenység, de Platón utal a misztériumok hasonló szerepére is. A görögöknél az istenek világához való felemelkedés mozzanata a misztérium beavatási szertartása éppúgy, mint a tragédiának az isteni rend helyreállása nyomán bekövetkező katharszisza. Szókratész, aki isteni sugallatra verseket kezd írni a börtönben, ezzel a közvetlenül múzsai tevékenységgel tisztítja meg magát, bár magát a filozófiát is a Múzsák adományának tartja. Az Euénosznak küldött üzenet „ha eléggé okos, mielóbb követ engem” kitétele sem pusztán és elsődlegesen a halál tényére értendő, hanem - különösen az elôbbi gondolat jelentésátsugárzása révén - mindenekelőtt a megtisztulás immanens mozzanatára.

Aki az erkölcsi értékek illetve az eszmélet elérése révén megtisztul, az beavatottként „az istenekkel fog lakni”, aki nem, az pedig disznóként sárban fog fetrengeni. Közvetlenül adódik ez esetben a Hérakleitosszal való összevetés lehetősége: DK 13., ill. DK 5. Minthogy Hérakleitosznál a „minden egy" jegyében az erkölcsi rend követése a kozmikus világegészbe való beilleszkedéssel azonos, a „Sárnak örülnek (a disznók)" kép gondolati háttere talán már eleve magában hordozta a megtisztulás szélesebb, az emberi létezés nem csupán földi szférájára kiterjedő értelmezését.

Míg a közgondolkodás az ideatant véli
Platón filozófiájának alapsajátosságának, addig a modern értelmezések egy része (pl. Karl Albert: Griechische Religion und platonische Philosophie, München, 1980. ${ }^{21}$ ) inkább az egység keresését tartja a platoni filozófia középponti kérdésének. A Phaidónban a világegész koherenciáját nem annyira a lélek halhatatlansága, hanem sokkal inkább a Jó egyetemes érvénye adja.

Platón megkülönbözteti az emberi és az istenvilág jellemzőit, ez az elkülönülés azonban a Jó perspektívájából újra egységbe olvad.

isteni
lélek
jó
önmagáért való elgondolással
bölesességszeretố
szembenézés a halállal
állandó

emberi
test
szívesen
érzékszervekhez kötốdổen
testszeretố
félelembôl bátor
változó

$\mathrm{Az}$ emberi az isteninek alárendelve alkotórésze az egészének, nem elegendő tehát csupán az életre összpontosítani (107 c). A halál azonban nem jelenti az élettól való következmények nélküli elszakadást. $\mathrm{Az}$ ember éthosza nem csak életében daimónja, hanem halála után is, s éppen ebból következik a jó és rossz megkülönböztetésének jelentősége. (Hérakleitosznál egy másik töredékben megtalálható ennek a platoni gondolatnak az elóképe is: „Nemesebb halállal nemesebb sorsot nyernek el" (DK 25).

Az eszmélet fogalmában - a Menónhoz hasonlóan - a Phaidónban is összekapcsolódik a lélek halhatatlanságának, a valóság megismerhetőségének és az erkölcsnek a problematikája. „Maga az eszmélet is nem más, mint bizonyos megtisztulás." (69 e). A lélek, amennyiben nem az érzékek révén, hanem "saját maga szerint vizsgálódik", akkor a tisztát, az örökkévalót keresi meg (79 d). (A gondolat inverze, miszerint a józan belátás elvesztése és a tisztátalanság összefügg, már Homérosznál is jelen van. Kirké az óvatlan hajósokat disznóvá varázsolja, a kükeón, a be- 
avatás itala, itt gonosz varázslat eszköze, nem hat azonban a „tarkaeszư” Odüsszeusz esetében. ${ }^{22}$ )

Az eszmélet az igazság, a jó megismerésére irányul, s a filozófus annyiban valóban a halálra készül, amennyiben célja a földi életben is az, hogy eljusson a jó közelébe, s ezáltal halála után „nagyon, nagyon jó" uraihoz, az istenekhez (63 c).

\section{A platóni felfogás hangsúlyeltolódá- sai Mendelssohn Phaidón-átdolgo- zásában}

Moses Mendelssohnt a filozófiatörténeti összefoglalások hagyományosan a populárfilozófia színvonalasabb múvelôi közé sorolják ${ }^{23}$. Jól érzékelhető nála is a populárfilozófiának az az alapvonása, hogy többnyire a problémák szimplifikálása árán - mindig egy tágabb olvasóközönséghez próbálja eljuttatni a filozófia ismereteket. ${ }^{24}$ A Jacobival Lessing és Spinoza viszonyáról folytatott vitája kapcsán szerepe volt a kanti rendszer formálódásában is ${ }^{25}$. Phaidón, oder die Unsterblichkeit der Seele címû 1767-ben megjelent mûve széleskörü ismertségre tett szert. ${ }^{26}$ Hegelnek egy fiatalkori naplóbejegyzése arról tanúskodik, hogy egykor ő is lelkes olvasója volt ennek a Platón-interpretációjának. ${ }^{27}$ Filozófiatörténetében természetesen már igen kritikusan szemléli Mendelssohnt. Morgenstunden című múvét azért bírálja, mert abban hasztalanul próbált a szerző „derűs platóni formát” adni száraz wolffi absztrakcióinak, a Phaidónt pedig úgy emlegeti, mint „amelyet Mendelssohn modernizált és wolffi metafizikává változtatott át”. ${ }^{28} \mathrm{~A}$ platoni dialógus lefordításában eleve benne van a populárfilozófia népszerüsítő attitűdje, de az azon eszközölt változtatások oka is jórészt ezen irányzat törekvéseiben kereshető. Mendelssohn munkáinak egyik központi eleme az emberi boldogság keresése. ${ }^{29}$ Ennek a közérdeklődésre számottartó kérdésnek a középpontba helyezése a Phaidón esetében azzal a következménnyel járt, hogy a Mendelssohn által három részre tagolt dialógus második és harmadik részében a kortárs irányzatok problémáinak popularizált vetületei váltak dominánssá, avagy - a felvilágosodás korabeli mú fordításjellegét tekintve - az eredeti platóni koncepciót veszélyeztető mérvüvé lett a „szöveg. romlás". ${ }^{30}$

Mendelssohn filozófiájának alapvonása az egyetemes vallási fogalmak megalapozása és az emberi boldogság (Glückseligkeit) keresése. ${ }^{31}$ Morálfilozófiájának sok forrása között a leibnizi minta a leginkább donináns, s ebból adódóan a jó mibenlétére vonatkozó egész platóni problematika ontológiai színezetet kapott nála, s egyszersmind el is veszítette sokszínúségét és frissességét.

Mendelssohn múvét az eredeti dialógus három érvének megfelelően osztotta fejezetekre.

$\mathrm{Az}$ elsó részben -amely az eredeti $\mathrm{Pla}$ tón mủ $57 \mathrm{a}-79 \mathrm{a}$ részének többé-kevésbé pontos fordítása - mellözi az öngyilkosság tilalmának platóni taglalását. ami kiindulópontja volt az istenek és az emberek világa közötti bonyolult viszony vizsgálatának. A XVIII. századi múben a harmonia praestabilita gondolata alapozza meg a világnak azt a tökéletességét, amelynek jegyében az öngyilkosság a harmonikus világrend megsértéseként jelentkezik. (Szókratész a módszerének eredetét taglaló részben - Phaidón, 95e -102 a Anaxagorasz kapcsán éppen azt a gondolkodásmódot utasította el, mely szerint „az ész a világban való rend egyetemes és egyetlen oka”, illetve hogy „minden a lehető legjobban van elrendezve.)

Platónnál a második érv lényege az, hogy „lélek igazi természete annak a sajátos jónak a természetéból ismerhető meg, amely felé a lélek törekszik." ${ }^{32}$ Taylor utal arra is, hogy Mendelssohnnál a hangsúly a lélek egyszerú szubsztancia jellegére kerül, s ez az a momentum amelyet Kant a 
tiszta ész paralogizmusai közé sorolva cáfol meg. ${ }^{33}$

A Mendelssohn mú harmadik része a Phaidón 95a - 106d fejezetét foglalja magában, s az eredetitól való legjelentôsebb eltérést Kebész ellenvetésének interpretációja mutatja. A püthagoreus harmóniára és a hérakleitoszi gondolatra ${ }^{34}$ visszavezethető érvelés helyét az öntevékeny monaszokból levezetett, s az emberre is jellemző természettól fogva való tökéletesedés eszméje foglalja el..$^{35}$

Mendessohn müve tehát a - még a $\mathrm{Pa}$ jor-féle fordításon keresztül is jól érzékelhető - szöveghü részletek ellenére is a platóni felfogás teljes átformálását valósította meg. Az előszóban így ír: „Nem a volt az én célom, hogy azokat a Lélek halhatatlansága felól való erôsségeket előszámláljam, amelyekkel bírt a Görög Bólts az ô idejébe, hanem hogy megmutassam, hogy mitsoda próbákat találna a mi idônkbe a Lélek halhatatlanságának megmutatására egy olyan ember, mint Szókratész." ${ }^{36}$
Ilymódon egy parafrázis jött létre, amely ahelyett, hogy - ha már túlment a fordításon - a Platón múnek egy a görög hagyományt értelmező popularizált interpretációját adná, a fóleg Leibnizre alapozott kortárs szemlélet vonatkoztatási rendszerévé teszi azt.

Egy ilyen megközelítés fényében különösen fontosnak tünik a Phaidón értelmezésének szempontjából a lélek halhatatlansága kérdésének preszókratikus eredete és a görög filozófiai hagyományba való beágyazottsága.

\section{Irodalom}

Arisztophanész vígjátékai. Bp., 1988.

Arisztotelész: Nikomakhoszi etika. Bp., 1987.

Burkert, Walter: Weisheit und Wissenschaft. Studien zu Pythagoras, Philolaos und Platon, Nürnberg, 1962.

Edwards, Paul (ed.): The Encyclopedia of Phylosophie V., New York-London, 1967.

Gigon, Olof: Der Ursprung der griechischen

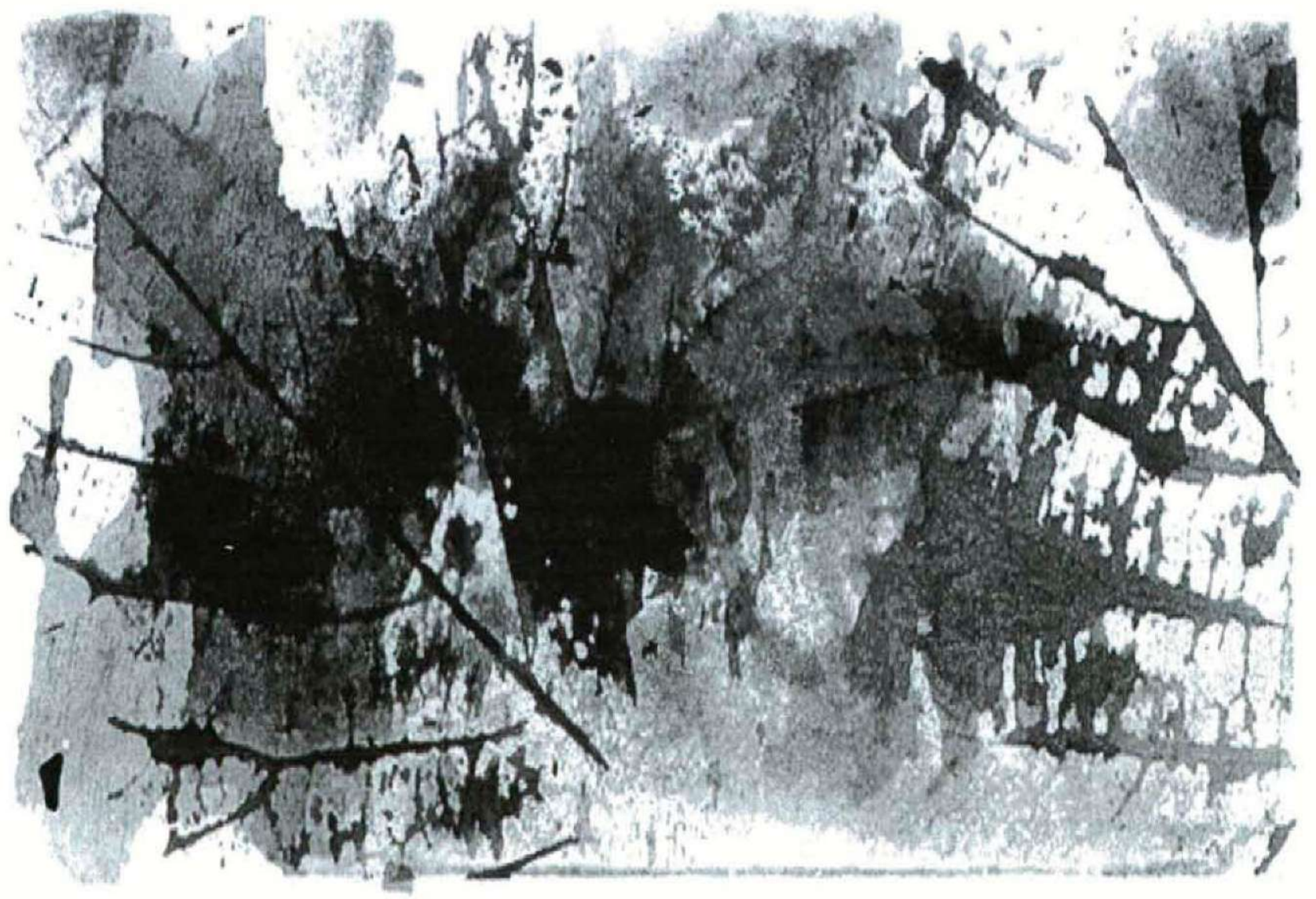


Philosophie. Basel,1945.

Guliga, Arseni: Hegel. Berlin, 1984.

Hegel, Georg Wilhelm Friedrich: Előadások a filozófia történetéról II. és III. Bp., 1979.

Kant, Immanuel: Tájékozódni a gondolatok között: mit is jelent ez? In: Vallás a puszta ész határain belül és más írások. Bp., 1974.

Kerényi Károly: Pythagoras és Orpheus. In: Halhatatlanság és Apollón-vallás. Bp., 1984., 472478.

Lux Zoltán: Karl Albert: Griechische Religion und platonische Philosophie. In: Magyar Filozófiai Szemle, 1982/5.

Mittelstrass, Jürgen: Encyclopädie der Philosophie und Wissenschaftstheorie. Stuttgart-Weimar, 1995.

Noack, Ludwig: Geschichte der Philosophie in gedrangter Uebersicht. Weimar, 1853.

(Pajor Gáspár név nélküli fordítása) Fédon, vagy a lélek halhatatlansága. Három beszélgetésekben írta német nyelven Mendelson Mózes. Magyarra fordíttatott egy magyar hazafi által. Pest, 1793.

Plutarkhosz: Iszisz és Oszirisz. Bp., 1986.

Plutarkhosz: Párhuzamos életrajzok. Bp., 1983.

Reichmann Győző: Mendelssohn Phaedonjának viszonya Platon Phaedonjához. Bp., 1940.

Röd, Wolfgang: Geschichte der Philosophie VIII. München, 1978.

Schoeps, Julius: Moses Mendelssohn. Königstein, 1979.

Szabó Árpád: Platón élete. Existentia, 1992/1-4.

Szilágyi Imre: Platonizmus. A platóni filozófia hatástörténete. In: Steiger Kornél (szerk.): A lakoma. Phaidrosz, Bp., 1994.

Taylor, Alfred Edward: Platón. Bp., 1997.

Ulrici, Hermann: Geschichte und Prinzipien der neueren Philosophie. Leipzig, 1845.

Zsoldos Jenő: Mendelssohn a magyar szellemi életben. Izraelita Magyarok Irodalmi Társaságának Évkönyve, 1933.

\section{Jegyzetek}

${ }^{1}$ Kerényi, 293.

${ }^{2}$ Taylor, 250.

${ }^{3}$ Gigon, 129.
4 Szilágyi Imre, 152-155.

${ }^{5}$ Taylor, 22.

${ }^{6}$ Szabó, 293.

${ }^{7}$ „A papok azt állítják, hogy nemcsak az említett istenek teste nyugszik náluk, hanem másoké is, akiket istenek nemzettek, de nem voltak halhatatlanok. Ezeknek teste náluk pihen és tiszteletben részesül, lelkük viszont az égbolton csillag. ként ragyog." Plutarkhosz, 25.

${ }^{8}$ „Szolga: Hát való-e amit mondanak:

Hogy aki meghal, ott csillag leszen?

Trygaios: Való hát!" Arisztophanész, 271.

${ }^{9}$ Burkert 338.

${ }^{10}$ A Phaidónban ábrázolt szókratészi magatartás a Párhuzamos életrajzokban - paradox módon egy öngyilkossággal összekapcsolva - egyfajta cselekvésmintaként bukkan fel, bizonyítva a dialógus népszerüségét a római antikvitásban. „Az uticai Cato, mikor látta már hogy elveszett az ügyük, Caesar lesz a győztes, és hogy neki, Catonak öngyilkosnak kell lennie, mieloott megölte volna magát, elolvasta még egyszer ezt a platóni dialógust, hogy a lélek halhatatlanságának hitével haljon meg." Plutarkhosz, Cato 70.

"Taylor, 253.

${ }^{12}$ „Az éthosza kinek-kinek számára a daimón” DK, B119.

${ }^{13}$ Taylor, 251-52.

${ }^{14}$ Taylor, 249-50.a

${ }^{15}$ Taylor, 261.

${ }^{16}$ Taylor, 275.

${ }^{17} \mathrm{~A}$ harmóniaelv feltétlen elôtérbehelyezésére Philolaosz az abszolút példa, aki a püthagoraszi elvek teljesítésének érdekében tizedik bolygóként az ellenföldet vette fel rendszerébe. DK, A 16.

${ }^{18}$ Taylor, 255

${ }^{19}$ Burkert, Sternwelt und Unsterblichkeit c. fejezet, 335-47.

${ }^{20}$ A testnek akadályozó szerepnek hasonló értelmezése található a Nikomakhoszi etikában is: "A gyönyör akadályozza a gondolkodást." Arisztotelész, VII. 13.

${ }^{21}$ Lux, 773.

${ }^{22}$ Homérosz, X. 233-330.

${ }^{23}$ Röd, 280-81.

${ }^{24}$ Mittelstraß, III. 296. 
${ }^{25}$ Kant, 109-10.

${ }^{26} \mathrm{~A}$ mű jó színvonalú kortárs magyar fordítását Pajor Gáspár, Kármán József barátja, az Uránia társszerkesztôje készítette el. Mendelssohn hazai népszerüségét egyik méltatója így jellemzi: „A Phädon ismerete kultúrkövetelmény volt a századvég magyar szellemi életében." Zsoldos, 67. (A továbbiakban az eredeti Mendelssohn könyv helyett a fordításra hivatkozom.) 1884-ben egy újabb fordítás jelent meg Debrecenben. A fordító, Farkas Glück Regina előszavából kiderül, hogy, nem tudott Pajor korábbi - s mellesleg jobb - átültetéséról. Az elóbbieken kívül létezik még egy olyan „magyarítás” is, amelynek a szerzôre való hivatkozáson túl vajmi kevés köze van az eredetihez (Bauer Marcussohn Hermann: A lélek halhatatlanságáról, Szeged, 1836.).

${ }^{27}$ Guliga: Hegel, 10.

${ }^{28}$ Hegel, III.382. és II. 148.

${ }^{29}$ Ulrici, 21. és 72 .
${ }^{30}$ Mendelssohn Lessighez írott leveleiból kitünik, hogy a kezdettól fogva átírásnak tervezett mü Szókratész-képének formálódásában nem csupán a platóni dialógusok játszottak szerepet, hanem a Phaidón szituációját feldolgozó kortárs müvek is. Ezek közül Haamann névtelenül megjelent művét (Socratische Denkwürdigkeiten) és Jacob Wegelin Letzte Gespräche des Socrates und seiner Freunde címú írását említi meg. Az életrajzi vonatkozásokat részben Cooper The Life of Socrates (London, 1749) címü könyvéból merítette. Schoeps, 83-86.

${ }^{31}$ Noack, 281. Az újabb szakirodalomban: Edwards, 276-77.

${ }^{32}$ Taylor, 268.

${ }^{33}$ vö. Röd, 292-94.

${ }^{34}$ Taylor,276.

${ }^{35}$ Reichmann, 37.

${ }^{36}$ Pajor, 5.

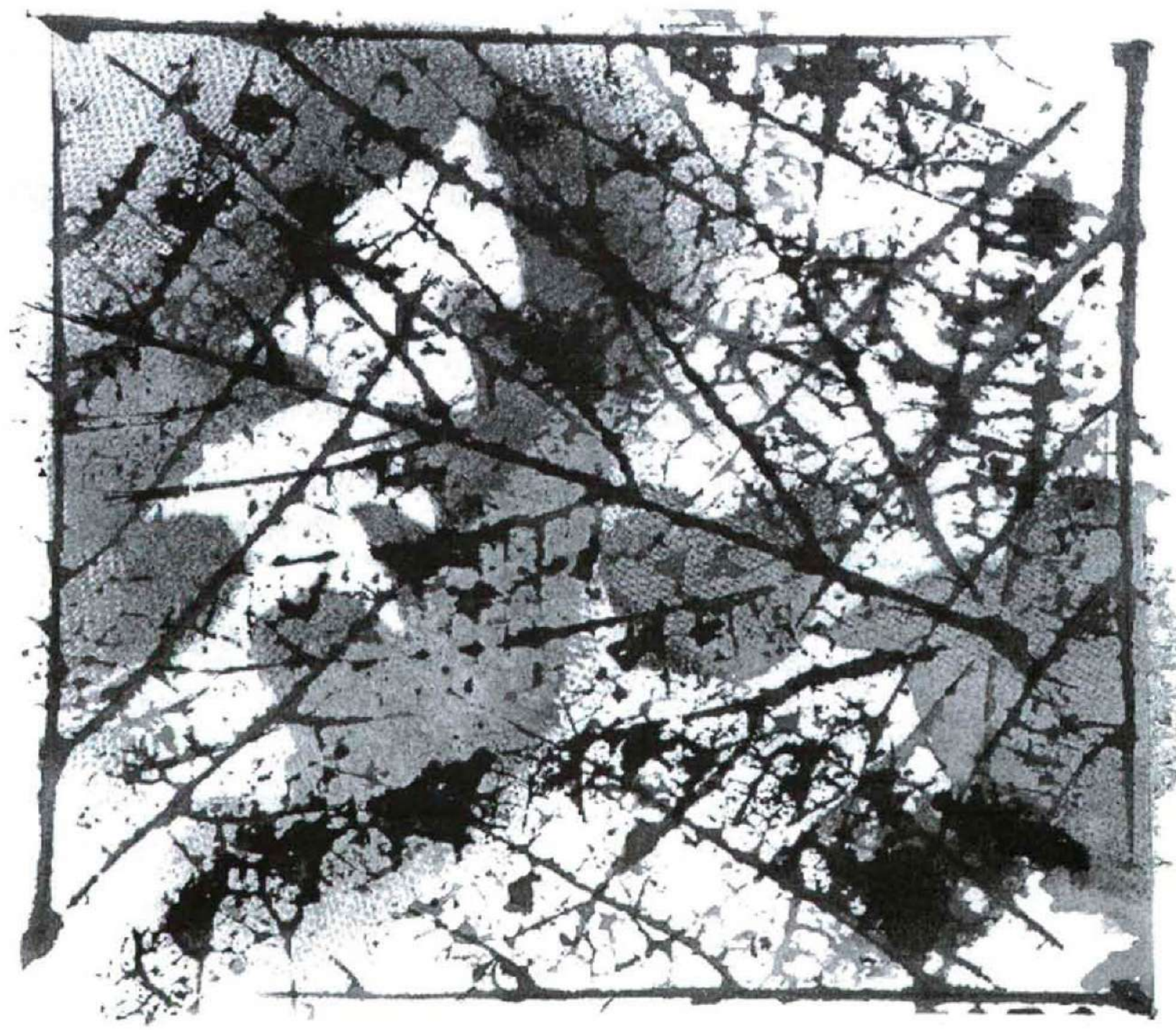

